Bolstad, R. (2004). School-based curriculum development: Principles, processes, and practices. Wellington, New Zealand: New Zealand Council for Educational Research.

Carl, A. (2005). The "voice of the teacher" in curriculum development: A voice crying in the wilderness. South African Journal of Education, 25(4), 223-228.

Erss, M., Mikser, R., Löfström, E., Ugaste, A., Rõuk, V., \& Jaani, J. (2014). Teachers' views of curriculum policy: The case of Estonia. British Journal of Educational Studies, 62, 393-411. doi:10.1080/ 00071005.2014 .941786

Glickman, C. D., Gordon Glickman, C. D., Gordon, S. P., \& Ross-Gordon, J. M. (2013). The basic guide to supervision and instructional leadership ( $3^{\text {rd }}$ ed., pp. 250-262). Boston: Pearson.

Handler, B. (2010). Teacher as curriculum leader: A consideration of the appropriateness of that role assignment to classroom-based practitioners. International Journal of Teacher Leadership, 3(3), 32-42.

Jadhav, M. S., \& Patankar, P. S. (2013). Role of teachers' in curriculum development for teacher education. Paper presented at the National Conference on Challenges in Teacher Education, Physical Education and Sports, Kolhapur, India.

Kelly, A. V. (2009). Curriculum Theory and Practice ( $6^{\text {th }}$ Edition). Los Angeles: Sage Publications.

Klein, M. F. (1991). A conceptual framework for curriculum decision making. In M. Klein (Ed.), The politics of curriculum decision making: Issues in centralizing the curriculum (pp. 24-41). Albany, NY: State University of New York.

Lunenberg, F., \& Ornstein, A. C. (2008). Educational administration: Concepts and practices (5 ${ }^{\text {th }}$ ed.). Belmont, CA: Wadsworth.

Marsh, C. J., \& Willis, G. (2003). Curriculum: Alternative approaches, ongoing issues (3 ${ }^{\text {rd }}$ ed.). Columbus, OH: Merrill.

Messick, R. G., \& Reynolds, K. E. (1991). Middle level curriculum in action. New York, NY: Longman.

Mullick, H. (2013). Voices imprisoned within classrooms: A critical approach to curriculum development and teacher voice on a preparatory year English language program in the Kingdom of Saudi Arabia. International Journal of Bilingual \& Multilingual Teachers of English, 1(2), 37-48.

Oliva, P. F. (2008). Developing the curriculum ( $7^{\text {th }}$ ed.). Boston, MA: Pearson.

Oloruntegbe, K. O. (2011). Teachers' involvement, commitment and innovativeness in curriculum development and implementation. Journal of Emerging Trends in Educational Research and Policy Studies, 2, 443-449.

Posner, G. J. (2003). Analyzing the curriculum ( $3^{\text {rd }}$ ed.). New York, NY: McGraw-Hill.

Syomwene, A. (2020). Curriculum theory: Practice and functions. European Journal of Education Studies, 7(1), 326337. doi:10.5281/zenodo.3718433

UNESCO International Bureau of Education (2011). Towards a quality education for all: the national curriculum framework 2011. Retrieved from https://unesdoc.unesco.org/ark:/48223/pf0000212722?posInSet=1\&queryId= e5867cf3-4276-4168-a345-0909605119d8

UNESCO International Bureau of Education (2013). Glossary of curriculum terminology. Retrieved from https://unesdoc.unesco.org/ark:/48223/pf0000223059?posInSet=2\&queryId=20e6eead-5e88-4e0a-b67a-ef31428cc6f7

UNESCO, (2014). EFA Global Monitoring Report 2013/4 - Teaching and Learning: Achieving Quality for All. Available at http://unesdoc.unesco.org/images/0022/002256/ 225660e.pdf

Voogt, J. M., Pieters, J. M., \& Handelzalts, A. (2016). Teacher collaboration in curriculum design teams: effects, mechanisms, and conditions. Educational Research and Evaluation, 22(4), 121-140.

Wiles, J., \& Bondi, J. (2007). Curriculum development: A guide to practice ( $7^{\text {th }}$ ed.). Upper Saddle River, NJ: Pearson/Merrill Prentice Hall.

Zohrabi, M. (2014). Promoting teacher development through an interactive approach to curriculum development. Procedia-Social and Behavioral Sciences, 98, 2025-2034. doi:10.1016/j.sbspro.2014.03.638 


\section{TEACHER'S AND LEARNER'S ROLES IN AUTONOMY-ORIENTED FOREIGN LANGUAGE TEACHING: A THEORETICAL INVESTIGATION}

\section{Dung Nguyen Tri Tran}

\section{Article History}

Received: July 29, 2020

Accepted: August 19, 2020

Published: September 30, 2020

\section{Keywords}

Autonomous learning, learner's roles, teacher's roles

\author{
Ho Chi Minh City University of Education, Vietnam \\ Email:dungtran.la@gmail.com
}

\begin{abstract}
The global language teaching community has largely spotlighted students' autonomous learning for the last few decades. Through the thorough review of the existing literature on learner autonomy, this article aims to theoretically investigate this concept as well as clearly specify the roles played by teachers and students in an autonomy-oriented classroom. Autonomous learning is not at all synonymous with the absolute elimination of teacher's role and learnerlearner relationships. In fact, language instructors need to comprehend their roles in a multidimensional way, and students are supposed to be responsibly active for their own learning process as well as positively interdependent for academic cooperation.
\end{abstract}

\section{INTRODUCTION}

In the recent years, such pedagogical issues as the prevalence of communicative approaches or digital literacy have been believed to characterize foreign language classrooms. The modern paradigm of language education, however, would not be the same without the movement from the obsolete teacher-domination to the vogue studentcenteredness. As Zhuang (2010) explained, this transition has arisen out of "the flaws in traditional teaching methods" which were unable to suit the learning style of each student and consequently made learning "passive and boring". The over-emphasis on instructors is also likely to rob students of their sense of responsibility, critical capacity and creativity for their own learning. The teacher-centered approach, therefore, fails to meet the crucial conditions of effective education, including the provision of problem-solving activities for students, learners' total engagement and teachers' minimum intervention (Barman, 2013). Those recognizable defects usually found in a teacher-focused classroom have paved the way for the establishment of a different pedagogical paradigm which fosters their ability to learn the target language independently. Nevertheless, since being autonomous means "doing things for yourself" (Little, 2004) or having freedom to act independently, there are indeed a few misconceptions allied to the theory and practice of learner autonomy. This paper, therefore, aims to investigate the concept of autonomous learning as well as specify the essential roles which are supposed to be played by teachers and students toward the make-up of a well-organized autonomy-oriented environment. From a theoretical perspective, this article helps to re-conceptualize language educators' idea about learner autonomy, and thus holds a great deal of significance for the improvement of such relevant practices as teaching, learning, course designing and teacher training, particularly given the pedagogical contexts across Asia, including Vietnam, where learner autonomy has still been challenged by various constraints (Dang, 2010; Nguyen, 2012; Phan, 2013).

\section{LITERATURE REVIEW}

\subsection{Conceptual formation of autonomy in language education}

In one of the earliest attempts to define learner autonomy (henceforth referred to as LA), Holec (1981, as cited in Yang, 2007, p. 2) described it as "the ability to take charge of one's own learning," which, according to Little (1996), corresponds to the image of a student with a high degree of self-direction and implies the matter of learner maturity. Allright (1990, as cited in Ramos, 2006, p. 184) emphasized the equilibrium between self-development and human interdependence, instead of traditionally seeing autonomy as individualistic behavior. Another considerable defining effort came from Littlewood (1996, p. 428), who specified two components of autonomy, i.e. ability and willingness, as follows:

Ability depends on possessing both knowledge about the alternatives from which choices have to be made and the necessary skills for carrying out whatever choices seem most appropriate. Willingness depends on having both motivation and confidence to take responsibility for the choices required. 
Even though the interpretations of LA possibly vary from scholar to scholar, many prominent common features of LA can be recognized from the aforementioned definitions and synthesized in the following working definition of LA: Autonomy in the ELT arena is a relative concept referring to the learner's highly motivated attitude and ability to be essentially responsible for and actively engaged in all aspects of the language learning process within a studentcentered, teacher-facilitated, cooperative context in order to become a competent language learning individual.

\subsection{Underlying theories behind LA}

In the domain of foreign language learning, LA is firmly built upon the robust foundation of the constructivist, social-cognitive and motivation-related theories. First of all, autonomous learning is a modern learning theory of constructivism which means the students take charge of their own learning by carrying out their own learning plans according to their own needs (Islam, 2011, p. 1080).

Secondly, the notion of LA is also grounded in Lev Vygotsky's social-cognitive theory of self-regulation, which involves two significant concepts of "scaffolding," i.e. the learning assistance offered by more competent others, and the "zone of proximal development," i.e. the difference between the learner's actual level and the potential level that could be reached with appropriate help (Oxford, 1999). Last but not least, the insight into LA also requires the understanding of motivation and its three relevant approaches, including the self-determination theory, attribution theory, and goal-oriented theory. Firstly, the self-determination theory focuses on the two important conditions for intrinsic motivation, i.e. learners' perception of the informational learning environment, and an autonomy-supporting context which facilitates students' self-determination (Deci \& Ryan, 1985, as cited in Dickinson, 1995, p. 166). The second is called the attribution theory, which shows that some learners tend to be more successful when they believe in their control over learning and accept new challenges (Dickinson, 1995). Finally comes the goal-oriented theory which concerns the reasons why students choose to engage in particular tasks or search for certain information to solve their personally relevant problems (Ma \& Ma, 2012).

\subsection{Remarkable merits of $L A$}

In general, learners who autonomously take responsibility for their learning are more likely to achieve their academic goals and even maintain the positive attitude toward learning in the future (Little, 1995). In the particular domain of language pedagogy, LA provides many opportunities for the use of various skills, through which students can enhance their language learning processes, e.g. self-regulation of activities, self-monitoring, working with others, or awareness of learning strategies (Ramos, 2006). The LA theory also puts a strong emphasis on the learner as a central, active figure in the academic environment, and this "active participation ensures success in language learning" (Ming \& Alias, 2007, p. 1). Significantly, it helps learners achieve a high degree of "creativity and independence" and lays the foundation of life-long learning, which explains why fostering LA should become "one of the most important goals that teachers and educators try to pursue" (Yan, 2012, p. 558). Last but not least, the down-to-earth necessity of autonomous learning may arise from real-world constraints, such as students' lack of time to follow a traditional course, the insufficient demand for a language to set up a standard teacher-led course, or limited staff-student contact time due to budgetary restrictions (Kojima \& Kojima, 2005).

\section{RESEARCH METHODS AND RESULTS}

On a theoretical basis, this study employs diverse sources of materials for deep insight into the issue under investigation. Specifically, this paper critically examines the existing literature found in a wide range of international peer-reviewed journal articles and proceedings in order to ensure that the analysis and synthesis of the data is reliably based on the scholarly and professional knowledge.

Employing the aforementioned interpretation of LA as the main conceptual foundation, this article goes to deeply discuss the identity of language teachers and learners in an autonomy-directed pedagogical context. From a more practical perspective, a certain number of relevant implications are then presented, mainly focusing on the teaching of language macro skills.

\subsection{Teacher's roles}

Since LA "is not equivalent with leaving learning to the exclusive responsibility of the student" (Ribbe \& Bezanilla, 2013, p. 110), teachers actually play an indispensable part in scaffolding the autonomy in language education. Their roles in the autonomy-based classroom are, nonetheless, distinctively distinguished from that in the teacher-centered language pedagogy, where it is the teacher's role to make decisions with regard to purposes of the work, focus of content, ways of undertaking the work and evaluation of students' performances, both covertly as part 
of planning and classroom management and through overt instructions at key moments in a lesson (Ma \& Ma, 2012, p. 841).

Rather, the teacher's identity in LA-oriented pedagogy is well determined under some specified terms, namely: an educational architect who creates a classroom environment conducive to student participation, an educational consultant who serves as an experienced coach working alongside of students during the learning process, and an educational assessor who evaluates learning outcomes and uses this information to help learners improve their learning (Barman, 2013, p. 54). At the same time, as a promoter of a multicultural perspective and a reflective practitioner and researcher, a language teacher ought to strike a balance between students' native culture and the target one, as well as the judicious blend of reflective research and teaching (Kojima \& Kojima, 2005, p. 69).

As can be inferred from the aforementioned literature, LA truly calls for the reconceptualization of how teachers work and act. In autonomy-oriented language classrooms, their roles are now to provide psychological support and strategy training for their students to develop autonomous learning (Zhuang, 2010), and to create a motivating environment by formulating relevant problems as well as linking them to learners' prior knowledge (Schreurs \& Dumbraveanu, 2014). Teachers are then expected to withdraw their total control and give students more involvement in making decisions throughout their learning process. In language education, no matter what specific skills are taught, students always feel excited about things to which they can relate; and, at this point, teachers' flexibility is highly needed for careful consideration of what to teach as well as how to deliver lessons. Taking an English lesson of descriptive writing for example, language teachers can motivate leaners by asking them to write about their favorite movie star or music idol. This initial interest in the lesson can help learners maintain their motivation and become more independent while working on the task.

Understandably, because "foreign language knowledge and skills appear to be very relevant to personal autonomy in a multilingual world" (Benson, 2012, p. 32), EFL teachers have a certain responsibility to foster LA, which requires much of their effort, patience, time and skills (Chan, 2000), especially within the Asian spoon-feeding educational system where language learners are used to following the lead of the instructor so as to pass examinations (Islam, 2011).

\subsection{Learner's roles}

Overall, an autonomous learner is often recognized through a diversity of skills, a focused approach to language learning, as well as the pursuit of successful learning despite the probability of failure (Nunan, 2000, as cited in Islam, 2011, p. 1081). However, in addition to the abundant approvals of such ideas as the personal responsibility for learning or self-reflection on academic improvement, LA has also been emphasized in terms of interdependence, i.e. "the ability of learners to work together for mutual benefit and to take shared responsibility for their learning" (Ivanovska, 2015, p. 353). Regarding the English speaking skill, for example, autonomy may occur when learners learn how to construct knowledge for themselves about how to speak in the target language that will be in addition to the teacher's prior scaffolding. For this reason, learners have to develop autonomy through an interdependence, rather than independence, with the teachers' instructional methods (Talley, 2014, p. 25).

This article accentuates the identity of autonomous learners in a communicative context because the highest level of LA should be achieved through dialogic negotiations and immediate interactions between students (Dang, 2010). As the factors of cooperative interaction and mutual support always play a vital role in effective communicative language classrooms, the practice of LA would not make full sense if it just involved individual learner. From an empirical perspective, Egel (2009, p. 2024) discovered a consensus on the importance of developing LA within the classroom "through the support of teachers and collaboration of the learners." Similarly, Chang (2007, as cited in Zarei \& Zarei, 2015, p. 266) also confirmed the correlation between group factors and English language students' autonomous behaviors, which implies a learner's possibility of getting positively influenced by their classmates' autonomy.

Once again, although autonomy may be mistakenly associated with the idea of learning in a strictly independent manner, there is indeed a sensible connection between autonomous and cooperative learning, with very little degree of conceptual contradiction. Rather, the practice of LA can even be strengthened via a reasonable amount of interdependence between individuals. In addition to the assistance and encouragement provided by the teacher, the mutual interaction among peers greatly contributes to the making of a communicative environment which is advantageous for students to reinforce their sense of responsibility and autonomous behavior in language learning. 


\subsection{Pedagogical implications}

The implementation of learner autonomy and collaboration is firmly believed to engender numerous values such as generating interactive language, offering secure environment for successful learning, resulting in increased motivation, or promoting a better sense of learner responsibility (Brown, 2001, as cited in Onozawa, 2010, p. 130). Given the essence and values of truly autonomous learning, the following table provides a number of concrete ideas on the basis of the four macro skills in English language pedagogy:

Table 1. Potential teaching activities for promoting autonomous language learning

\begin{tabular}{|c|c|}
\hline English skill & Suggested teaching ideas \\
\hline Listening & $\begin{array}{l}\text { - Training students with various strategies to deal with different listening task types } \\
\text { (e.g. multiple-choice questions, gap-filling, matching); } \\
\text { - Treating listening questions in textbooks with flexibility and modifying them if } \\
\text { necessary; } \\
\text { - Introducing extra materials for home practice (with both questions and keys for } \\
\text { students' self-reference); } \\
\text { - Encouraging students to listen to one TED Talk per week (or other interesting } \\
\text { speeches which can be found on social media platforms), and, in class, share with others } \\
\text { what they have learnt from it. }\end{array}$ \\
\hline Reading & $\begin{array}{l}\text { - Training students with scanning and skimming practice; } \\
\text { - Giving students practical tips to deal with different reading task types (e.g. multiple- } \\
\text { choice questions, gapped texts, true-false-not given items); } \\
\text { - Using authentic texts, whenever possible, for intensive reading practice; } \\
\text { - Getting students involved in extensive reading activities, alternatively followed by } \\
\text { oral discussion or written reflection. }\end{array}$ \\
\hline Speaking & $\begin{array}{l}\text { - Selecting topics relevant to students' real-life experiences or interests; } \\
\text { - Asking students to record monologues for teacher's feedback or peer evaluation; } \\
\text { - Maximizing students' talking time via some creative projects, e.g. interviews with } \\
\text { foreigners, individual vlogs, etc. } \\
\text { - Encouraging students sincerely and trying not to make them too afraid of using the } \\
\text { foreign language, especially when they make unserious errors during practice. }\end{array}$ \\
\hline Writing & $\begin{array}{l}\text { - Conducting group brainstorming before asking students to work individually on a } \\
\text { writing topic; } \\
\text { - Emphasizing the pre-writing stage to help students build up confidence for more } \\
\text { autonomous learning afterward; } \\
\text { - Carrying out joint-writing activity with the participation of the teacher and all class } \\
\text { members: Students contribute ideas, build sentences or form paragraphs under teachers' } \\
\text { immediate prompts and corrections; } \\
\text { - Using social networking sites to encourage more students' writings (e.g. writing } \\
\text { Facebook statuses or commenting in English). }\end{array}$ \\
\hline
\end{tabular}

As can be seen from these suggestions, the crucial elements of individual responsibility, positive cooperation with peers and external facilitation from teachers are well integrated, all for the development of autonomous learning. The autonomy-oriented teaching practice actually revolves around the three core principles of involving learners in the decision-making process (1), supporting their self-monitoring (2), and scaffolding the immersion of students in authentic learning environments (3) (Ribbe \& Bezanilla, 2013). In the $21^{\text {st }}$-century language pedagogical context, the promotion of LA should be practically connected to the utility of Internet-based activities in order to assist collaborative interaction and learner control (Benson, 2001, as cited in Kruk, 2012, p. 115).

\section{DISCUSSION AND CONCLUSION}

All in all, this article provides an in-depth discussion on the multidimensional identity of teachers and learners in an autonomy-based English language teaching environment, as opposed to what they basically do in the conventional language classroom. For the optimal development of LA, it is equally important for language teachers to understand 
the true nature of autonomous learning and re-conceptualize their own functions. When it comes to the notion of LA, the identification of the learner as a central, independent individual in the learning process has been excessively accentuated at the expense of teacher-learner-learner relationships. Rather, in the proper interpretation of LA, the independent role of learners should be fully fostered along with the positive interdependence between fellows and the sensible support from the teacher.

Built upon the major foundations of social constructivist learning and motivation, LA yields a great number of pedagogical merits and has thus received tremendous appreciation from the language teaching community despite its complicated nature. In its full sense, LA refers to students' willingness and ability to take responsibility for important decisions in their own learning process within the supportive environment which is made up of learner centeredness, teacher facilitation and well-organized cooperation between peers.

Upon such awareness, the significance held by language teachers in an autonomy-supportive setting is not de facto on the decline even though they essentially keep themselves away from the supreme classroom power. Instead, they are supposed to simultaneously adopt a variety of facilitating roles, such as a resourceful guide, a creative supporter, a reflective counselor, who provides students with appropriate assistance, sufficient motivation, constructive feedback, and effective atmosphere for learning.

The proper recognition of autonomous students does not only lie in the amount of accountability which they take for their own learning, but also highlights their positive interdependent behavior. In other words, academic collaboration by no means negates learners' exercise of autonomy as it creates an interactive context where students' sense of responsibility is well reinforced and their target-language communication is securely aided.

\section{REFERENCES}

Barman, B. (2013). Shifting education from teacher-centered to learner-centered paradigm. Retrieved from http://daffodilvarsity.edu.bd/images/conference/contant/Shifting\%20Education\%20from\%20Teacher-Centered\%20 to\%20Learner-Centered\%20Paradigm.pdf

Benson, P. (2012). Autonomy in language learning, learning and life. Synergies France, 9, 29-39.

Chan, V. (2000). Fostering learner autonomy in an ESL classroom. TESL Canada Journal, 18(1), 75-86.

Dang, T. T. (2010). Learner autonomy in EFL studies in Vietnam: A discussion from sociocultural perspective. English Language Teaching, 3(2), 3-9.

Dickinson, L. (1995). Autonomy and motivation: A literature review. System, 23(2), 165-174.

Egel, I. P. (2009). Learner autonomy in the language classroom: from teacher dependency to learner independency. Procedia - Social and Behavioral Sciences, 1, 2023-2026. doi:10.1016/j.sbspro.2009.01.355

Islam, M. N. (2011). Independent English learning through the Internet. Journal of Language Teaching and Research, 2(5), 1080-1085. doi:10.4304/jltr.2.5.1080-1085

Ivanovska, B. (2015). Learner autonomy in foreign language education and in cultural context. Procedia - Social and Behavioral Sciences, 180, 352-356. doi:10.1016/j.sbspro.2015.02.128

Kojima, H., \& Kojima, Y. (2005). Teacher roles in learner-centered communicative EFL instruction. Bulletin of the Faculty of Education, Hirosaki University, 94, 59-72.

Kruk, M. (2012). Using online resources in the development of learner autonomy and English pronunciation: The case of individual learners. Journal of Second Language Teaching and Research, 1(2), 113-142.

Little, D. (1995). Learner as dialogue: The dependence of learner autonomy on teacher autonomy. System, 23(2), 175-181.

Little, D. (1996). Learner autonomy: Some steps in the evolution of theory and practice. The Irish Yearbook of Applied Linguistics, 16, 1-13.

Little, D. (2004). Democracy, discourse and learner autonomy in the foreign language classroom. Utbildning \& Demokrati, 13(3), 105-126.

Littlewood, W. (1996). “Autonomy”: An anatomy and a framework. System, 24(4), 427-435.

Ma, Z., \& Ma, R. (2012). Motivating Chinese students by fostering learner autonomy in language learning. Theory and Practice in Language Studies, 2(4), 838-842. doi:10.4304/tpls.2.4.838-842

Ming, T. S., \& Alias, A. (2007). Investigating readiness for autonomy: A comparison of Malaysian ESL undergraduates of three public universities. Reflections on English Language Teaching, 6(1), 1-18. 
Nguyen, N. T. (2012). "Let students take control!" - Fostering learner autonomy in language learning: An experiment. International Proceedings of Economics Development and Research, 30, 318-320.

Onozawa, C. (2010). Promoting autonomy in the language class - How autonomy can be applied in the language class. Retrieved from http://www.kyoai.ac.jp/college/ronshuu/no-10/onozawa1.pdf

Oxford, R. L. (1999). Relationships between second language learning strategies and language proficiency in the context of learner autonomy and self-regulation. Revista Canaria de Estudios Ingleses, 38, 109-126.

Phan, T. T. T. (2013). Developing autonomy in an East Asian classroom: from policy to practice. International Proceedings of Economics Development and Research, 68(2), 6-10. doi:10.7763/IPEDR.2013.V68.2

Ramos, R. C. (2006). Considerations on the role of teacher autonomy. Colombian Applied Linguistic Journal, 8, $183-202$

Ribbe, E., \& Bezanilla, M. J. (2013). Scaffolding learner autonomy in online university courses. Digital Education Review, 24, 98-113.

Schreurs, J., \& Dumbraveanu, R. (2014). A shift from teacher centered to learner centered approach. International Journal of Engineering Pedagogy, 4(3), 36-41. doi:10.3991/ijep.v4i3.3395

Talley, P. C. (2014). Students' responses to learner autonomy in Taiwan: An investigation into learners' beliefs. International Journal of Humanities and Social Sciences, 4(4), 24-34.

Yan, S. (2012). Teachers' roles in autonomous learning. Journal of Sociological Research, 3(2), 557-562. doi: $10.5296 /$ jsr.v3i2.2860

Yang, T. (2007). Changes in learner autonomy by means of journal writing: From the point of view of learners. Proceedings of the Independent Learning Association 2007 Japan Conference. Chiba: Kanda University of International Studies.

Zarei, A. A., \& Zarei, N. (2015). On the effect of language proficiency on learners' autonomy and motivation. Journal of English Language and Literature, 3(2), 263-270.

Zhuang, J. (2010). The changing role of teachers in the development of learner autonomy - Based on a survey of "English Dorm Activity". Journal of Language Teaching and Research, 1(5), 591-595. doi: 10.4304/ jltr.1.5.591-595. 